\title{
Universal Banking, Conflicts of Interest and Firm Growth
}

\author{
Lili Xie* \\ Department of Economics \\ Ball State University \\ lxie@bsu.edu
}

July 25,2007

\begin{abstract}
This paper studies the relationship between universal banking and firm performance. With 40 developing and developed countries, I find that the overall effect of universal banking on firm growth is negative. This suggests that the negative effect of conflicts of interest dominates the positive effect of economies of scale and scope in universal banking. However, in countries with stronger protection of creditors' rights and higher information efficiency, conflicts of interest are less likely and the negative relationship between universal banking and firm growth is significantly weaker.
\end{abstract}

JEL: G21, O16

Keywords: Universal Banking, Firm Incentive, Conflicts of Interest, Economies of Scope, Economies of Scale.

*Address: Department of Economics WB201, Ball State University, Muncie, IN 47306. Tel:765-285-5378. This paper is adapted from Chapter II of my dissertation at the University of Illinois at Urbana-Champaign. I am especially indebted to my advisor, Charles Kahn, for continuous support and help. I am grateful to Murrilo Campbell, George Pennacchi, and Juha Seppala for valuable advice. I thank Robert DeYoung, Douglas Evanoff, Craig Furfine, Hesna Genay, Mitchell Petersen, Tara Rice, and Richard Rosen for helpful comments. I also benefited from comments of seminar participants at Ball State University, University of Illinois at Urbana-Champaign, Federal Reserve Bank of Chicago, 2006 SEA meeting, and 2007 MFA meeting. All remaining errors are mine. 
Since King and Levine (1993), a large literature has appeared with convincing evidence that efficient financial systems accelerate long-run economic growth (e.g., Levine and Zervos, 1998; Rajan and Zingales, 1998). In fact, international financial institutions such as the World Bank and IMF have strongly urged countries to adopt appropriate regulatory and supervisory measures in their financial systems to promote economic growth (see Barth, Caprio and Levine, 2001a).

This paper focuses on a particular regulatory practice, that is, regulatory restrictions on commercial banks conducting security businesses such as security underwriting and trading. Countries across the world have granted different degrees of freedom for their commercial banks to get into financial businesses besides commercial lending and deposit taking. Germany and similar European countries have adopted "universal banking systems," permitting a wide range of activities. The United States, which originally restricted commercial banking activities, has greatly relaxed those restrictions since adopting the Gramm-Leach-Bliley Act in 1999. In contrast, developing countries have generally maintained higher restrictions on banking activities.

Previous studies have investigated the issue of broadening commercial bank powers from different perspectives. One strand of literature has conducted single-country studies to see whether conflicts of interest will result from allowing commercial banks to underwrite securities. Evidence found generally rejects this hypothesis (e.g., Kroszner and Rajan, 1994; Gande et. al, 1997; Hebb and Fraser, 2002 and 2003). Yet a caveat is that these studies are based on developed countries and may not be generalized to developing countries. In fact, using cross country data, Laeven and Levine (2007) find a diversification discount associated with banks getting into other financial businesses, which suggests intensified agency problems in such banks. However, also using cross country data, Barth, Caprio, and Levine (2001a, 2001b) find that lower regulatory restrictions on banking activities are associated with a significantly lower probability of major banking crisis.

This paper differs from previous studies by studying the microeconomic impact of combining commercial banking and security businesses (universal banking ${ }^{1}$ ) on firm performance using data from both developed and developing countries. Although findings from existing studies shed some light on this issue, none has studied the relationship directly. For in-

\footnotetext{
${ }^{1}$ In general, universal banking refers to banks conducting a wide range of businesses including security, real estate, insurance businesses and etc. In my paper, since I only focus on the ability of commercial banks to conduct security businesses, I use "universal banking" interchangeably with the combining of commercial banking and security businesses.
} 
stance, studies of the U.S. case generally find that universal banking leads to lower cost of finance and better access to finance for firms (e.g., Gande et. al, 1997; Drucker and Puri, 2005), which suggests a potentially positive relationship between universal banking and firm growth. However, affecting firms' access to credit is not the only channel through which universal banking can affect firm growth.

Theoretically, allowing commercial banks to conduct security businesses can have two opposing effects on firm performance. On one hand, economies of scope and scale in universal banking can facilitate firms' access to credit and promote firm growth. Commercial banks can apply information produced in commercial lending to security businesses and save information production costs (e.g., Greenbaum et al., 1989; Rajan, 1996). If the information cost savings are passed on to firms, firms will benefit from lower finance costs and higher access to credit, leading to higher firm growth. In addition, economies of scale in universal banking, which allows better risk diversification and lowers transaction costs for banks, can also lead to similar effects. On the other hand, combining commercial banking and security businesses may also introduce the possibility of conflicts of interest, creating disincentives on firms and lowering firm growth. To be more specific, if banks are able to underwrite securities for their borrowing firms, they may have incentives to help firms issue securities by hiding or distorting information when firm quality has deteriorated and credit risk has increased to their private knowledge. In this case, the security proceeds can be used to pay off the outstanding loans and the higher credit risk can be shifted to the uninformed public investors. This conflict of interest can significantly weaken bank monitoring since firms can expect to be bailed out instead of being liquidated by universal banks in times of financial distress. As bank monitoring plays a very important role in controlling moral hazard incentives in debt contracts such as bank loan contracts, the weakening of bank monitoring in universal banking will lead to higher incentives of firm managers to engage in activities which bring private benefits to themselves but hurt firm prospects (e.g., Kanatas and Qi, 1998; Xie, 2005). For instance, they may choose low or even negative net present value projects which bring them large enough private benefits. If this inefficiency brought by the conflict of interest is serious enough, firm growth will be negatively affected.

With firm level data from 40 developed and developing countries, I find that firms in countries that allow commercial banks to engage in security businesses face lower difficulty in financing, consistent with the existence of economies of scale and scope in universal banking. 
However, the positive effect of economies of scale and scope on firm financing is dominated by the negative effect of conflicts of interest on firm incentives as shown by the lower growth of firms in universal banking countries. To minimize the possibility that something other than conflicts of interest is causing the result, I examine the differential effects between small and large firms ${ }^{2}$. If conflicts of interest indeed contribute to lower firm growth in universal banking countries, large firms should be more negatively affected than small firms are as it is quite unlikely for small firms to issue securities and therefore the likelihood of conflicts of interest is low for banks dealing with them. This is confirmed by the regression results. In addition, by examining the interaction between the regulatory restrictions on security businesses and several country characteristics which affect the likelihood of conflicts of interest, I find that the negative relationship between universal banking and firm growth is weaker in countries where the likelihood of conflicts of interest is lower. In particular, countries with higher institutional development, stronger security laws, higher accounting standards or higher information efficiency of the stock market experience lower negative effects from universal banking.

Examining whether the organizational structure of universal banks affects the relationship between universal banking and growth, I find that firms experience significantly lower growth in countries that allow in-house operations of security businesses in commercial banks than in countries that require security businesses to be conducted in separate subsidiaries. This is consistent with the finding in Kroszner and Rajan (1997) that conflicts of interest are more likely in universal banks that conduct security businesses in internal departments.

Although previous studies using data from developed countries fail to find evidence for conflicts of interest, my findings suggest that when good institutions which can control conflicts of interest incentives are lacking, a country may need to guard against potential costs from universal banking. This justifies the higher inclination of developing countries to require their commercial banks to conduct security businesses in separate subsidiaries rather than in internal departments if they allow commercial banks to conduct security businesses at all.

This paper contributes to the literature in three respects. First, it complements the finance-growth literature with additional evidence on the mechanism through which finance affects growth. Previous studies have examined the effects of banking competition on firm

\footnotetext{
${ }^{2}$ This is kindly suggested by the anonymous referee.
} 
credit availability and growth (e.g., Petersen and Rajan, 1995; DeYoung, Goldberg, and White, 1999; Cetorelli and Gambera, 2001). Studies have also investigated whether whether having a bank-based or market-based financial system matters for economic growth (e.g., Tadesse, 2002; Levine, 2002; Demirguc-Kunt and Maksomovic, 2002). In addition, the connection between universal banking and real economic performance has been discussed. Schumpeter (1939) and Gerschenkron (1962) are among the early works to find that universal banks played an important role in the industrialization of Continental European countries such as Germany. More recently, Calomiris (1995) and Da Rin and Hellman (2002) provided some additional historical evidence for the connection between universal banking and industrialization. Using cross country data, Barth, Caprio, and Levine (2001a, 2001b) documented the impact of universal banking on financial development and banking crisis from a macroeconomic perspective. Yet the literature lacks direct empirical evidence, especially microeconomic evidence, on how universal banking affects economic growth and development. This paper is an attempt to fill this void. With the additional evidence, we will have more information regarding how different aspects of finance work together to influence the real economy.

Second, this paper provides empirical evidence relevant to universal banking in developing countries. There has been a large literature discussing the effects of commingling commercial lending and other financial activities in developed countries, mostly the United States. Berger and Udell (1996) and Elya and Robinson (2004) find that U.S. banks with security affiliates generally engage in less small business lending. Using data before the Glass-Steagall Act was enacted, Kroszner and Rajan (1994) and Puri (1994, 1996) find that commercial bank affiliate underwritten issues do not perform worse than similar investment bank underwritten issues and neither do they sell for a lower price. Gande et. al (1997) find similar results using data in the 1990s. Cornett et. al (2002) examine bank performance after banks established section 20 subsidiaries for security underwriting and find that banks experienced higher returns without bearing higher risk after expanding their activities. In addition, several studies have focused on how investment banking and commercial banking affect each other and majority of the evidence from U.S. data suggests that there are significant cost savings when these two businesses are merged (e.g., Drucker and Puri, 2005; Roten and Mullineaux, 2002; Yasuda, 2005). Despite all this evidence regarding developed countries, there has been much less evidence on the effects of universal banking in developing countries. 
Since social and economic conditions in developing countries are significantly different from those in developed countries, the previous findings may not apply to developing countries. In fact, this paper shows that country characteristics can affect the benefits and costs of universal banking significantly. For developing countries, where institutional development is low and protection of investors' interests is weak, conflicts of interest may be a problem worth guarding against in universal banking.

Lastly, this paper provides further evidence on whether the organizational form of universal banks can help reduce conflicts of interest. Kroszner and Rajan (1997) and Puri (1996) find conflicting evidence regarding this issue. My evidence supports the view of Kroszner and Rajan (1997) that the subsidiary structure can reduce the likelihood of conflicts of interest.

The rest of the paper is organized as follows. Section 1 describes the sample data. Section 2 discusses the main results while robustness results are given in section 3 . Section 4 concludes.

\section{Data and Variables}

\subsection{Regulatory Restrictions on Banking Activities}

Measures of regulatory restrictions on banking activities are obtained from the Bank Regulation and Supervision database compiled by the World Bank, which provides information for 118 countries on the ability of commercial banks to engage in security businesses among others $^{3}$. Regulatory restrictiveness on banks conducting security businesses is quantified on a scale of 1 to 4 . Respectively, the values 1 to 4 indicate a certain activity is 'Unrestricted', 'Permitted', 'Restricted', or 'Prohibited' ${ }^{4}$. This measure is constructed based on information around 1999. Although our sample period is 1997-1999, it should raise no concern for endogeneity as no country in my sample changed its regulations on banking activities during this period according to Table 12 in Barth, Caprio and Levine (2001b). The lower the variable is, the lower the restrictions on security businesses are and the more "universal" a banking system is. For instance, Germany, generally considered as having the most typical

\footnotetext{
${ }^{3}$ Besides security businesses, the Bank Regulation and Supervision database also provides information on regulations of banks engaging in insurance and real estate businesses and ownership of nonfinancial firms.

${ }^{4}$ 'Unrestricted' means a full range of activities in the given category can be conducted directly in the bank; 'Permitted' means a full range of activities can be conducted but all or some must be conducted in subsidiaries; 'Restricted' means less than a full range of activities can be conducted in the bank or subsidiaries; and 'Prohibited' means the activity cannot be conducted in either the bank or subsidiaries.
} 
universal banking system, has a value of 1 for 'Security'. This suggests that Germany allows commercial banks to conduct a full range of security businesses in-house.

\subsection{Firm Level Data}

My firm level data is taken from the World Business Environment Survey (WBES2000) conducted in 80 developing and developed countries by the World Bank in late 1999 and early 2000. The survey asked the firms to report their sales growth over the previous three years. This is then used as the measure of firm growth in my study. In addition, the survey obtained from firms such information as the number of employees, industry, number of competitors, share of state ownership, share of foreign ownership, and whether the firm exports.

Among the 80 countries in the World Business Environment Survey, information on regulatory restrictions on banking activities is available only for 60 countries. In addition, 20 countries have missing data for country level control variables used in the basic regression ${ }^{5}$. To make sure that my results are not contaminated by any effect from these control variables, I only consider the 40 countries that have a full set of information. As a result, the only two countries among the 60 countries that prohibit commercial banks from doing any security business ('Security'=4), China and Cambodia, drop out of my sample ${ }^{6}$. In particular, China has missing data for the share of bank assets in government-owned banks while Cambodia doesn't have information for most of the country level controls. To avoid potential accounting errors, I also remove firms that report extreme accounting growth ${ }^{7}$. With these restrictions, 3461 firms from 40 developing and developed countries remain in my sample.

In firm level regressions, I control for important firm characteristics that can affect firm growth. Dummies for firm size, defined according to the number of employees, are included. 'Small' equals 1 if firms have 5-50 employees and 'Medium' equals 1 if firms have 51-500 employees. The omitted category is 'Large', which equals 1 for firms with over 500 employ$\mathrm{ees}^{8}$. Four industry dummies indicating whether the firm is in the manufacturing, service,

\footnotetext{
${ }^{5}$ These variables contain information about log of GDP per capita, GDP growth, inflation rate, institutional development, financial development, economic freedom from government intervention, and share of bank assets in government-owned banks.

${ }^{6}$ In the robustness check section, it is checked that this doesn't affect the results.

${ }^{7}$ For the results reported in this paper, growth rates greater than $300 \%$ or less than $-70 \%$ are considered as extreme. With this restriction, 1450 observations are removed. Other criteria for removing outliers have also been tried and the same qualitative results are obtained.

${ }^{8}$ Value of sales is not included as a control because it is not reported for firms in East European countries.
} 
construction or agriculture industry respectively are used to account for the different investment opportunities in different industries ${ }^{9}$. Exporters and firms with foreign ownership may have more investment opportunities and dummies for them are included as well. In addition, I control for the number of competitors firms report, which can have a negative impact on firm investment opportunities. Finally, a dummy for government ownership is included as a firm level control. Government involvement may introduce bureaucracy and reduce the efficiency of a firm and is thus expected to have a negative effect on firm growth.

\subsection{Financial System Variables}

Some researchers are concerned that universal banking may lead to the dominance of a few large banks in all financial services, which would unduly benefit the usual customers of large banks, i.e., large nonfinancial firms, at the cost of efficiency. In this case, universal banking may have negative effects on economic growth through depressing competition. To avoid confusing the effects of universal banking discussed before with the effect of competition, I use four alternative measures to control for banking competition: 'Concen3', 'Concen5', 'Denied', and 'Foreign Bank Share'. 'Concen3' is the share of the three largest banks in total banking assets, which is a commonly used measure of banking system concentration. A similarly common measure is the percentage of deposits accounted for by the five largest banks, 'Concen5'. The variable 'Denied' is the share of banking license applications rejected and hence measures the difficulty of entry in banking. 'Foreign Bank Share', calculated as the share of assets in banks that are majority foreign owned, measures foreign bank entry and presence. Lower values for 'Concen3', 'Concen5', and 'Denied' and higher values for 'Foreign Bank Share' indicate more competitive banking systems. Some have argued that foreign bank presence and entry restrictions are better measures of banking competition than concentration ratios (e.g. Claessens and Laeven, 2004). However, I will take an agnostic attitude here and consider all four alternative measures in different regressions ${ }^{10}$.

Financial development and structure may also affect growth and are controlled for in regressions. More developed financial systems tend to be more efficient at facilitating firm finance. Although evidence on whether financial structure matters for growth is mixed, it is also included to control for any potential effect. I use the measures of banking system and

However, regressions that control for value of sales with East European countries removed give qualitatively similar results.

${ }^{9}$ The industry category left out is 'Other'.

${ }^{10} \mathrm{I}$ include one measure at a time. 
stock market development often considered in the literature to construct measures of financial development and structure (e.g. Rajan and Zingales, 1998; Levine, 2002). The variable used to measure banking system development is 'Private Credit', which is the ratio of bank claims on the private sector to GDP. 'Market Capitalization', the ratio of stock market capitalization to GDP, measures stock market size. Combining measures of banking system development and stock market development, I calculate the overall financial development and financial structure of a country. 'Financial Development' is calculated as the logarithm of the sum of 'Private Credit' and 'Market Capitalization' while 'Financial Structure' is calculated as the logarithm of the ratio of 'Private Credit' to 'Market Capitalization'. A higher value of 'Financial Structure' implies a more bank-based financial system.

The presence of state-owned banks in a banking system is also controlled for in regressions. State-owned banks often do not allocate credit based on market signals and thus may reduce the efficiency of a banking system (e.g., La Porta et al., 2002; Sapienza, 2004). As a result, a banking system dominated by state-owned banks may be associated with lower firm performance. Information on state-owned bank presence is obtained from the Bank Regulation and Supervision Database. 'State-owned Bank Share', which equals the share of assets in banks that are majority state-owned, captures this feature of the financial system.

\subsection{Other Country Level Variables}

To control for other country characteristics that can affect economic growth, I collect data from four different sources: International Financial Statistics, Reynolds and Flores (1996), Kaufman, Kraay and Zoido-Lobaton (1999), and the Heritage Foundation.

Data on the macroeconomic conditions of a country is obtained from International Financial Statistics provided by IMF. In particular, Log of GDP per capita is included to control for the convergence effect of the economy to its long-run steady state. Since the inflation rate measures the monetary stability of a country, it is expected to have a negative impact on economic growth and is included as a country control as well. Real GDP growth captures the abundance of investment opportunities in an economy in general and thus may affect firm growth positively.

Information on the origin of a country's legal system is collected from Reynolds and Flores (1996). The variable 'Civil' takes value 1 if the country has a civil law tradition and 0 if common law tradition. Since the legal codes of quite a few civil law countries in my 
sample were once influenced by different types of civil law ${ }^{11}$, I do not further distinguish between the different types of civil law. This should not make a big difference for the results since it is found that common law countries generally have better protection of creditor and shareholder rights than civil law countries (e.g., La Porta et al., 1998) and firms in common law countries face lower financing obstacles than firms in civil law countries no matter whether it is French, German or Scandinavian civil law (e.g., Beck, Demirguc-Kunt and Levine, 2005). In my sample, $70 \%$ of the countries are of civil law origin.

The variable 'Institution' is a measure for the overall institutional development of a country and is taken from Kaufman, Kraay and Zoido-Lobaton (1999). It is the average value of six indicators measuring political stability, regulatory quality, government effectiveness, control of corruption, the extent to which the citizens of a country can participate in the selection of governments and the independence of the media, and the extent to which agents have confidence in and abide by the rules of the society. Higher values of this variable indicate higher levels of institutional development. Institutional development of a country facilitates its financial development and is expected to have a positive effect on firm growth.

I also control for overall government intervention in the economy to ensure that the four variables for universal banking do not capture the negative effects of an overbearing and intervening government on economic growth. The Heritage Foundation provides such information on an annual basis starting with 1995. The variable 'Economic Freedom', averaged for 1996-1999 in this paper, is an overall index of 50 institutional factors determining economic freedom such as the ease of opening businesses, the bureaucratic burden on businesses, corruption, the relative openness of a country's banking and financial system, government consumption as a share of GDP, government ownership of businesses and industries, and protection of private property rights. The institutional factors are put on a scale of 1 to 5 with higher values indicating less economic freedom and averaged to obtain 'Economic Freedom'. More detailed explanations of this variable is given in the Appendix.

Table 1 presents the values of some important country level variables by country. Countries are ranked by GDP per capita from the lowest to the highest. As can be seen from this table, developed countries generally have very low restrictions on security businesses except for the United States ${ }^{12}$. Summary statistics of all variables are given in Table 2. Table 3

\footnotetext{
${ }^{11}$ The paper covers more countries than in La Porta et al. (1998) and therefore can not use La Porta et al. (1998) as a complete guide in further classifying civil law countries.

${ }^{12} \mathrm{By}$ the time the data was collected the Glass Steagall Act hadn't been passed and thus the United States still had high restrictions on banks conducting security businesses.
} 
shows that the regulatory restrictions on security businesses are negatively correlated with GDP per capita, institutional development, economic freedom ${ }^{13}$ and financial development. This suggests that developed countries are more likely to have universal banking systems than developing countries.

[Table 1 about here]

[Table 2 about here]

[Table 3 about here]

\section{Regression Results}

\subsection{Universal Banking and Firm Growth}

Table 4 presents the results for OLS regressions of firm sales growth on firm level and country level variables introduced in the previous section. In particular, since developed countries, which tend to grow at low and steady rates, are more likely to allow universal banking, I control for GDP per capita, institutional development, and economic freedom to avoid capturing this effect. The errors are estimated with Huber-White sandwich estimator of variance clustered by country to adjust for any correlation among firms in the same country. From this table, we can see that firms in countries that allow commercial banks to conduct security businesses tend to be associated with lower growth relative to those in countries that restrict the commingling of commercial and investment banking. Based on column (a), a firm moving from a country that allows commercial banks to engage in a limited range of security business ('Security'=3, Mexico) to a country that allows commercial banks to conduct a full range of security business in subsidiaries ('Security' $=2$, Argentina) experiences a decrease in growth rate of 7.52 percentage points, all else equal. Since the average growth rate across all firms is 17.71 percent, this implies an economically significant effect. Although the result may not be accurate enough to make predictions, at least it suggests that overall the negative effect of conflicts of interest dominates the positive effect of economies of scale and scope on

\footnotetext{
${ }^{13}$ Note that the variable "Economic Freedom" actually measures the lack of economic freedom. Hence, the positive correlation coefficient actually indicates a negative relationship between security business restrictions and economic freedom.
} 
firm growth when commercial and investment banking are combined.

To further test whether conflicts of interest are indeed causing the results, I examine the differential effects across firm sizes. As small firms seldom issue securities, we should expect the likelihood of conflicts of interest to be lower and thus the negative impact of universal banking to be smaller for them ${ }^{14}$. In column (e) of Table 4, I replace 'Security' with its three interaction terms with firm size dummies. Recall that firms are classified as small if they have 5-50 employees, medium if 51-500 employees, and large if over 500 employees. It can be seen that the coefficient on the interaction term with 'Small' is lower than the other two, which indicates that the negative impact of universal banking is indeed lower for small firms as expected. Another interesting result is that the effect on medium firms is found to be larger than the effect on large firms. This result further supports the conflicts of interest hypothesis: since medium firms are more established than small firms and are no longer too small to issue securities but meanwhile they are more informationally opaque than large firms, it will be easier for universal banks to engage in conflicts of interest behavior, i.e., help them issue securities by distorting or hiding negative information to pay off outstanding loans ${ }^{15}$. As a result, the negative impact of universal banking induced by conflicts of interest will be larger for medium firms.

\section{[Table 4 about here]}

As an additional check of the conflicts of interest channel, I also examine how the negative effect of universal banking on firm growth varies when the likelihood of conflicts of interest varies across countries. If findings are attributed to conflicts of interest, we should expect the negative effect to be stronger when the likelihood of conflicts of interest is higher and to be weaker when the likelihood of conflicts of interest is lower. This is confirmed by results reported in Table 5. In column (a), I add the interaction term between 'Security' and 'Institution' to the baseline regression. 'Institution', which is constructed by Kaufman, Kraay and Zoido-Lobaton (1999), measures the extent to which members of a society have confidence in and abide by the rules of the society, government effectiveness and regulatory quality besides other aspects of institutional development. Hence, bankers in countries with

\footnotetext{
${ }^{14}$ I thank the anonymous referee for pointing this out.

${ }^{15}$ Large firms attract more media attention than medium firms and it would be more difficult for universal banks to hide negative information about them.
} 
higher values of 'Institution' may be less likely to engage in conflicts of interest behavior. The interaction term has a negative coefficient of -4.15. Although it is not significant, it is suggestive that the negative impact of universal banking on firm growth tends to be somewhat lower when conflicts of interest are less likely.

As 'Institution' considers six aspects of institutional development and some of them may not be particularly helpful for controlling conflicts of interest, I then focus on laws regarding security issuance, which directly regulate information disclosure in security issuance. Presumably, in a country with strong laws that protect investors' interests in security issuance, universal banks will be less able and less likely to distort information or hide negative information in security underwriting. La Porta et al. (2006) provide information on three aspects of security laws: 'Disclosure', 'Liability' and 'Public Enforcement'. 'Disclosure' measures the extent to which detailed information about an issuing company such as ownership structure and irregular transactions is required to be disclosed in the prospectus. Higher values for this variable indicate higher information disclosure requirements and it is thus more difficult for underwriters to hide essential information. 'Liability' considers the responsibility of investors to produce evidence in court when trying to recover losses from security issuance. In the case of fraud, it will be easier for investors in countries with higher values of 'Liability' to recover losses as the burden of producing proof is lower in these countries. 'Public Enforcement' measures the power of the supervisor of financial markets to issue regulations, to investigate violation of securities laws, to sanction responsible parties from taking certain actions and to criminate responsible parties. Higher values for this variable indicate stronger power of the supervisor to enforce securities laws, which increases the chance of discovering and punishing conflicts of interest behavior and thus can effectively dampen negative incentives of universal banks.

Results reported in columns (b)-(d) of Table 5 demonstrate that the negative impact of universal banking on firm growth is indeed lower in countries with stronger security laws. In particular, strong public enforcement seems to be the most effective in reducing the negative impact of universal banking. Based on column (d), if a country with the medium value for 'Public Enforcement' (0.6) decides to lower restrictions on security business by one level ${ }^{16}$, firms in this country will experience a decrease in growth of 14.77 percentage points ${ }^{17}$, all else

\footnotetext{
${ }^{16}$ For instance, 'Security' is reduced from 3 to 2 , which means the country used to allow only a limited range of security businesses be conducted by commercial banks but now permit a full range of security businesses to be conducted by subsidiaries of commercial banks.

${ }^{17}$ This number is calculated as $35.24+(-34.11) \times 0.6$.
} 
equal. In contrast, if a country with the highest value for 'Public Enforcement' (0.9) decides to do so, the decrease is only 4.54 percentage points. Besides, the decrease in firm growth is no longer statistically significant. The large impact of public enforcement of security laws can be attributed to its particularly effective deterrence of conflicts of interest behavior in universal banking.

Besides direct legal requirements, accounting standards in a country can also affect information disclosure and thus the ability of universal banks to engage in conflicts of interest behavior. The Center for International Financial Analysis and Research (CIFAR) construct an index which shows the amount of information disclosure of companies' annual reports in a country. Stronger accounting standards in a country make it more difficult to manipulate earnings and other essential information and thus reduce the possibility of conflicts of interest. The negative coefficient on the interaction term in column (e) shows that stronger accounting standards decrease the negative impact of universal banking on firm growth. One standard deviation increase in accounting standards (8.7) lowers the negative impact of universal banking by approximately 4 percentage points.

In column (f), I explore the possibility that information sharing among financial institutions reduces conflicts of interest opportunities and thus reduces the negative effect of universal banking. 'Credit Registry' indicates whether a country has a private credit registry that provides information on the creditworthiness of firms. Such credit registries facilitate information sharing between financial institutions on their borrowing firms and thus make it more difficult for banks to distort or hide information. The negative coefficient on the interaction term indicates that the existence of a private credit registry indeed lowers the negative impact of universal banking on firm growth significantly. In countries with credit registries, universal banking no longer has a significantly negative impact on firm growth.

A similarly important aspect that affects the likelihood of conflicts of interest besides information disclosure is the extent to which stock prices incorporate firm specific information. In a innovative paper, Morck, Yeung and Yu (2000) introduces such a measure by considering the synchronization of stock price movements in different countries ${ }^{18}$. A low value for this measure, i.e., low synchronization of stock price movements, indicates that more firm specific information is capitalized into stock prices and it is thus more difficult for universal banks to issue stocks of low quality and get high security proceeds. Due to the dampening

\footnotetext{
${ }^{18}$ I thank the anonymous referee for suggesting this measure and also pointing out the direction of finding other relevant variables to me.
} 
effect of stock price informativeness on conflicts of interest behavior, we should expect the negative impact of universal banking on firm growth to be lower in countries with lower stock price synchronization. Regression results reported in column (g) confirm this prediction. In a country with no comovement between stock prices (stock synchronization equals 0), lowering restrictions on security business by one level, i.e., moving toward universal banking, increases firm growth by 8 percentage points. However, if stock synchronization increases by one standard deviation (0.13), moving toward universal banking will lower firm growth by 7.17 percentage points ${ }^{19}$.

These results suggest that developing countries have more reasons to guard against conflicts of interest between commercial lending and security underwriting since they generally have lower institutional development, weaker protection of investors' interests, weaker accounting standards and lower information efficiency of the stock market.

[Table 5 about here]

\subsection{Organizational Structure of Universal Banking}

In the debate regarding the Glass-Steagall Act in the United States, it is argued that if nontraditional businesses are conducted in separately incorporated subsidiaries firewalls can be set up between commercial banking and security business to reduce the potential for conflicts of interest. In search of evidence for this claim, Kroszner and Rajan (1997) find that bond issues underwritten by the internal investment banking departments of commercial banks have yields significantly higher than those underwritten by the independent affiliates of commercial banks in the United States before 1933. This finding supports the claim that there is a greater likelihood of conflicts of interest when commercial lending and security underwriting are conducted under the same roof. However, also using data before 1933 to study yield differentials, Puri (1996) find results suggesting otherwise.

The results reported in Table 6 are consistent with the finding in Kroszner and Rajan (1997). In these regressions, 'Security' is stripped into three dummy variables with each variable indicating a different level of restrictions on security activities. As no country in my sample prohibits security business by commercial banks completely, I only have three dummy

\footnotetext{
${ }^{19}$ This is calculated as $-8.81+122.96 \times 0.13$.
} 
variables corresponding to when 'Security' equals 1 ('unrestricted'), 2 ('permitted'), and 3 ('restricted') respectively. In the regressions, the omitted category and thus the benchmark is 'restricted', i.e., only a restricted range of security business can be conducted. The difference between 'unrestricted' and 'permitted' is that the former means that a full range of security activities can be conducted directly in the bank while the latter means that a full range of security activities can be conducted but all or some must be conducted in subsidiaries. Loosely speaking, it is the difference between German-style universal banking and U.S.-style universal banking after the Glass-Steagall Act was repealed. As shown in the table, the coefficients on both 'Security1' and 'Securtiy2' are negative, indicating lower firm growth in universal banking countries. In addition, the coefficient on 'Security1' is significantly more negative than the coefficient on 'Securtiy2'. This result suggests that firm growth is lower in countries where security businesses can be conducted in an internal department of the universal bank than in countries where some or all security businesses must be conducted in separate subsidiaries. This is consistent with a higher likelihood of conflicts of interest in internal-department-structure universal banks.

[Table 6 about here]

\subsection{Universal Banking and Firms' Access to Finance}

All the results above show the importance of conflicts of interest in the real economic impact of universal banking and suggest that under certain circumstances the negative impact from conflicts of interest could result in lower firm growth in universal banking countries. However, the mechanism through which conflicts of interest affect firm growth is less clear. Some may argue that conflicts of interest lead to lower firm growth by depressing firms' access to finance since creditors, who are concerned about conflicts of interest, may be reluctant to buy or charge a high interest rate on securities underwritten by universal banks. To see whether this indeed explains the previous findings, I examine the relationship between universal banking and firms' access to finance using the same firm level dataset.

In the World Business Environment Survey (WBES2000), firms are asked to judge on a four point scale how problematic financing is for the operation and growth of their business. Answers vary from 1 (no obstacle) to 4 (major obstacle). The categorical variable that results from this question is then used as a measure of credit constraint or the lack of credit 
accessibility by firms with higher values indicating higher credit constraint or lower access to finance. Average credit constraint faced by firms varies a lot across countries. Firms in Portugal report an average credit constraint of 1.69 while firms in Moldova report an average credit constraint of 3.46 .

As the measure of credit constraint only takes four ordinal values, I use the ordered probit model with errors adjusted for correlations at the country level to estimate the regressions. Similar control variables as in the firm growth regressions are included. As shown by the significantly positive coefficients on "Security" in columns (a)-(d) of Table 7, higher restrictions on security businesses are associated with higher credit constraint, i.e., universal banking actually facilitates firms' access to finance rather than reduces it. This suggests that if conflicts of interest have any negative impact on firms' credit accessability at all, it has been offset by the positive impact from economies of scale and scope.

To test whether conflicts of interest work through raising firms' cost of finance, I replace the general financing constraint with a variable which measures how much of a problem high interest rates pose for a firm's business. This variable also takes four values with higher values indicating higher credit constraint caused by high interest rates. The result reported in column (e) of Table 7 again supports the overall positive impact of universal banking on firms' access to finance: firms find high interest rates less of a problem in universal banking countries.

These results suggest that a mechanism other than reducing firms' financing availability is generating the negative impact of universal banking on firm growth. As financial arrangements can have significant impact on firms' incentives and investment efficiency, a plausible mechanism is that conflicts of interest in universal banking distort firm incentives and exacerbate moral hazard problems. Expecting to be bailed out by universal banks in times of financial distress, firm managers are more likely to choose inefficient investment projects as long as potential private benefits are high enough. Hence, although economies of scale and scope in universal banking facilitate firm finance, the inefficiency introduced by conflicts of interest dominates the positive impact and leads to lower firm growth. This suggests that the incentive effects of financial arrangements have important implications for real economic performance and should be treated as an important issue in financial system design just like firms' financing availability.

[Table 7 about here] 


\section{Robustness Tests and Discussion}

As economic growth is generally lower in developed countries than in developing countries, it may be a concern that the negative relationship found between universal banking and growth captures the sclerotic growth rate of developed countries and their higher tendency to adopt universal banking. For instance, economic growth in European Union countries has been stagnating and these countries also have a long history of universal banking. Although I have controlled for the differences in development with GDP per capita and a measure of institutional development, I add a further check by considering sub-samples in which developed countries are removed. In Column (b) of Table 8, I remove all countries in the European Union by 2000 and re-estimate the regression model. The coefficient on 'Security' is larger relative to the full sample, which suggests that the negative relationship between universal banking and firm growth becomes stronger. Similarly, the coefficient also increases when I remove all developed countries ${ }^{20}$ as shown in Column (c). Since developing countries generally have lower institutional development, weaker securities laws, weaker accounting standards and higher information asymmetry, these findings further support the conflicts of interest channel through which universal banking affects firm growth.

[Table 8 about here]

In my regression sample, 9 percent of the firms have government ownership. Governmentowned firms may have different incentives from private firms and may also be particularly favored by the government in terms of easier access to funds. If countries with a larger proportion of government owned firms are less market-oriented and tend to impose higher restrictions on banking activities, the effect of universal banking may have been biased by the lower presence of government-owned firms in economies with universal banking systems. In regard to this concern, I remove firms with government ownership from my sample and reestimate the regressions. With this restriction, only 3143 firms remain in sample. Regression results are also qualitatively similar to those for the larger sample ${ }^{21}$.

As noted in the data section, China and Cambodia were removed from the sample because of missing data for country level controls. This was unfortunate because these are

\footnotetext{
${ }^{20}$ Countries in my sample considered as developed countries are Canada, France, Germany, Italy, Portugal, Spain, Sweden, UK, and US.

${ }^{21}$ The results of these and the remaining robustness tests are available upon request.
} 
the only two countries in the full sample which were known to prohibit commercial banks from engaging in the security business. It is possible to include China and Kenya if the control variable "State-owned Bank Share" is omitted. When this is done, the results are qualitatively similar suggesting that all the results apply to the case when commercial banks are prohibited to do any security business.

In my sample, the United States is the only developed country that is considered as having a specialized banking system ('Security'=3). Other developed countries allow commercial banks to conduct a full range of security businesses either in-house ('Security'=1) or in subsidiaries ('Security'=2). However, in fact, since 1987, the Federal Reserve has started granting banks, on a case-by-case basis, the permission to establish Section 20 subsidiaries and engage in certain security businesses. In addition, the firewalls between these Section 20 subsidiaries and their parent banks have been gradually removed over the years in the 1990s. Hence, even before the Glass-Steagall Act, there has been a commingling of commercial banking and investment banking businesses in the United States. As the United States has a growth rate higher than the average and median growth rate of the sample during the sample period of 1997-1999, it raises the concern that whether the presence of the United States in the sample may have biased the regression results. By removing the United States from the regression, I find that the results are stronger but are qualitatively the same.

\section{Conclusion}

More and more countries are relaxing regulatory restrictions on banking activities. Among them, most are developed countries. Should developing countries follow suit? This paper suggests that conflicts of interest and the potential negative impact on growth that they bring should remain as a major concern for policy makers in developing countries. By studying the relationship between regulatory restrictions on banking activities and firm growth, I find that conflicts of interest are not much of a problem for countries with high institutional development and strong protection of investors' interests. However, if these conditions are not satisfied, lower firm growth may result from allowing commercial banks to engage in security businesses. Since institutional development takes a relatively long time, my finding also suggests that an alternative way to control conflicts of interest is to require universal banks to conduct security businesses in separately capitalized subsidiaries. 


\section{References}

Barth, James. R., Caprio, Gerard Jr., and Ross Levine, 2001a, Financial Regulation and Performance: Cross-Country Evidence, in Hernandez, Leonardo and Schmidt-Hebbel, Klaus eds.: Banking, Financial Integration and International Crises, Central Bank of Chile.

Barth, James. R., Caprio, Gerard Jr., and Ross Levine, 2001b, Banking systems around the globe: Do regulation and ownership affect performance and stability? in Frederic S. Mishkin, ed.: Prudential Supervision: What Works and What Doesn't (University of Chicago Press, Chicago, Ill.).

Beck, Thorsten, Demirguc-Kunt, Asli, and Vojislav Maksimovic, 2004, Banking competition and access to finance: International evidence, Journal of Money, Credit and Banking, 36(3), 627-648.

Beck, Thorsten, Demirguc-Kunt, Asli, and Vojislav Maksimovic, 2005, Financial and legal constraints to firm growth, Journal of Finance, 60(1), 137-177.

Berger, A.N. and Udell, G.F., 1996. Universal banking and the future of small business lending. In Anthony Saunders and Ingo Walter, eds., Universal Banking: Financial System Design Reconsidered. Irwin Professional Publishing, Chicago, 558-627.

Boot, Arnould W.A., and Anjan V. Thakor, 1997, Banking scope and financial innovation, Review of Financial Studies, 10(4), 1099-1131.

Calomiris, C.W., 1995. Universal banking and the financing of industrial development. World Bank Policy Research Working Paper 1533.

Cetorelli, N. and Gambera, M., 2001, Banking market structure, financial dependence and growth: international evidence from industry data, Journal of Finance 56, 617-648.

Claessens, Stijn and Luc Laeven, 2004, What drives bank competition? Some international evidence, Journal of Money, Credit, and Banking 36(3), 563-583.

Cornett, M. M., E. Ors, et al., 2002, Bank performance around the introduction of a section 20 subsidiary, Journal of Finance 57(1), 501-521.

Da Rin, M. and Hellman, T. 2002. Banks as catalysts for industrialization. Journal of Financial Intermediation 11(4), 366-97.

DeYoung, R., Goldberg, L. G. and White, L. J., 1999, Youth, adolescence and maturity of banks: credit availability to small business in an era of banking consolidation, Journal of Banking and Finance 23, 463-492. 
Demirguc-Kunt, A. and Maksimovic, V., 2002, Funding growth in bank-based and marketbased financial systems: evidence from firm level data, Journal of Financial Economics 65, 337-363.

Djankov, Simeon, Caralee McLiesh and Andrei Shleifer, 2007, Private Credit in 129 Countries, Journal of Financial Economics, forthcoming, 2007.

Drucker, Steven, and Manju Puri, 2005, On the benefits of concurrent lending and underwriting, Journal of Finance 60(6), 2763-99.

Elya, D. P. and K. J. Robinson, 2004, The impact of banks' expanded securities powers on small-business lending, Review of Financial Economics 13, 79-102.

Gande, Amar, Puri, Maju, Saunders, Anthony, and Ingo Walter, 1997, Bank underwriting of debt securities: Modern evidence, Review of Financial Studies 10(4), 1175-1202.

Gerschenkron, A., 1962. Economic Backwardness in Historical Perspective. Harvard University Press, Cambridge, MA.

Gorton, Gary and Frank A. Schmid, 2000, Universal banking and the performance of German firms, Journal of Financial Economics 58, 29-80.

Greenbaum, Stuart I., Kanatas, George and Itzhak Venezia, 1989, Equilibrium loan pricing under the bank client relationship, Journal of Banking and Finance 13(2), 221-235.

Hebb, Gregory M. and Donald R. Fraser, 2002, Conflicts of interest in commercial bank security underwritings: Canadian evidence, Journal of Banking and Finance 26, 19351949.

Hebb, Gregory M. and Donald R. Fraser, 2003, Conflicts of interest in commercial bank security underwritings: United Kingdom evidence, Quarterly Journal of Business and Economics 42, 79-95.

Kanatas, George and Jianping Qi, 1998, Underwriting by commercial banks: Incentive conflicts, scope economies, and project quality, Journal of Money, Credit and Banking 30(1), 119-133.

Kaufmann, Daniel, Kraay, Aart, and Pablo Zoido-Lobaton, 1999, Government matters, World Bank Policy Research Working Paper No. 2196.

King, R.G. and Levine, R., 1993, Finance, entrepreneurship and growth-Theory and evidence, Journal of Monetary Economics 32(3), 513-42.

Konishi, Masaru, 2002, Bond underwritings by banks and conflicts of interest: Evidence from Japan during the pre-war period, Journal of Banking and Finance 26, 767-793. 
Kroszner, R.S. and Rajan, R.G., 1994. Is the Glass-Steagall Act justified? A Study of the U.S. experience with universal banking before 1933. American Economic Review 84, 810-832.

Kroszner, Randy S. and Raghuram G. Rajan, 1997, Organizational structure and credibility: Evidence from commercial bank securities activities before the Glass-Steagall Act, Journal of Monetary Economics 39, 475-516.

Laeven, Luc and Levine, Ross, 2007, Is there a diversification discount in financial conglomerates? Journal of Financial Economics, forthcoming.

La Porta, Rafael, Lopez-de-Silanes, Florencio, Shleifer, Andrei, and Robert W. Vishny, 1998, Law and finance, Journal of Political Economy 106(6), 1113-55.

La Porta, Rafael, Lopez-de-Silanes, Florencio, and Shleifer, Andrei, 2002, Government ownership of banks, Journal of Finance 57(1), 265-301.

La Porta, Rafael, Lopez-de-Silanes, Florencio, and Shleifer, Andrei, 2006, What works in securities laws, Journal of Finance 61(1), 1-32.

Levine, Ross, 2002, Bank-based or market-based financial systems: Which is better? Journal of Financial Intermediation 11, 398-428.

Levine, R. and Zervos, S., 1998, Stock markets, banks and economic growth, American Economic Review 88(3), 537-58.

Morck, Randall, Yeung, Bernard, and Yu, Wayne, 2000, The information content of stock markets: why do emerging markets have synchronous stock price movements? Journal of Financial Economics 58, 215-260.

Petersen, M. A. and R. G. Rajan (1995), The effect of credit market competition on lending relationships, Quarterly Journal of Economics 110(2), 407-443.

Puri, M., 1994. The long-term default performance of bank underwritten security issues. Journal of Banking and Finance 18, 397-418.

Puri, Manju, 1996, Commercial banks in investment banking: Conflicts of interest or certification role? Journal of Financial Economics 40, 373-401.

Rajan, Raghuram G., 1996, The entry of commercial banks into the securities business: A selective survey of theories and evidence, in Anthony Saunders and Ingo Walter eds.: Universal Banking: Financial System Design Reconsidered (Irwin Professional Publishing, Chicago, ill.).

Rajan, Raghuram G. and Luigi Zingales, 1998, Financial dependence and growth, American 
Economic Review, 88(3), 559-586.

Reynolds, Thomas H. and Flores, Arturo A., 1996. Foreign Law: Current Sources of Codes and Legislation in Jurisdictions of the World ( Fred B. Rothman \& Co., Littleton, col.).

Roten, I. C. and D. J. Mullineaux, 2002, Debt underwriting by commercial bank-affiliated firms and investment banks: More evidence, Journal of Banking \& Finance 26: 689C718.

Santos, Joao A.C. and Adrienne S. Rumble, 2006, The American Keiretsu and universal banking: investing, voting and sitting on nonfinancials' corporate boards, Journal of Financial Economics 80, 419-454.

Sapienza, Paola, 2004, The effects of government ownership on bank lending, Journal of Financial Economics 72, 357-384.

Schumpeter, J., 1939. Business Cycles (McGraw-Hill, New York).

Tadesse, S., 2002, Financial architecture and economic performance: International evidence, Journal of Financial Intermediation 11(4), 429-54.

Xie, Lili, 2005, Essays on banking and interest rates, UIUC dissertation.

Yasuda, Ayako, 2005, Do bank relationship affect the firm's underwriter choice in the corporate-bond underwriting market? Journal of Finance 60(3), 1259-1291.

\section{Appendix}

\subsection{Variable Explanations and Data Sources}

- Firm Level Variables (All from WBES (2000) of World Bank):

- Sales Growth: average sales growth over the past three years as of the time of the survey.

- General Credit Constraint: whether financing poses a problem for a firm's growth and operation. This variable takes four values: 1 (no obstacle), 2 (minor obstacle), 3 (moderate obstacle), and 4 (major obstacle).

- High Interest Rate: whether high interest rates pose a problem for a firm's growth and operation. This variable also takes four values: 1 (no obstacle), 2 (minor obstacle), 3 (moderate obstacle), and 4 (major obstacle).

- Export: whether the firm is an exporter.

- Govern: whether the firm has government ownership. 
- Foreign: whether the firm has foreign ownership.

- Small: whether the firm is a small firm (5-50 employees).

- Manufacture: whether the firm is in the manufacturing industry.

- Service: whether the firm is in the service industry.

- Construction: whether the firm is in the construction industry.

- Agriculture: whether the firm is in the agriculture industry.

- Log of Competitors: logarithm of the number of competitors.

- General Country Characteristics:

- Inflation: average inflation rate over 1996-1999. From International Financial Statistics and World Economic Outlook.

- GDP per capita: average GDP per capita over 1996-1999. From International Financial Statistics and World Economic Outlook.

- GDP growth: real growth rate of GDP averaged over 1996-1999. From International Financial Statistics and World Economic Outlook.

- Economic Freedom: an overall measure of the absence of government coercion or constraint on the economy. It considers 10 categories of institutional factors including 1) how easy or difficult it is to open and operate a business; 2) government's direct use of scarce resources for its own purposes and government's control over resources through ownership; 3) the fiscal burden a government imposes on its citizens through taxes; 4) the relative openness of a country's banking and financial system; 5) the degree to which a country's laws protect private property rights and the degree to which its government enforces those laws; 6) the level of corruption; 7) the extent a government allows the market to set wages and prices; 8) restrictions on foreign investment; 9) inflation; 10) tariff rate. From the Heritage Foundation. Averaged for 1996-1999.

- Financial System Characteristics:

- Security: a measure of regulatory restrictiveness in commercial banks engaging in the business of securities underwriting, brokering, dealing, and all aspects of the 
mutual fund industry. From World Bank Regulation and Supervision Database (2001). This variable takes the values of 1-4, with larger numbers representing greater restrictiveness:

1) Unrestricted indicates that a full range of activities in the given category can be conducted directly in the commercial bank.

2) Permitted indicates that a full range of activities can be conducted but all or some must be conducted in subsidiaries.

3) Restricted indicates that less than a full range of activities can be conducted in the bank or subsidiaries.

4) Prohibited indicates that the activity cannot be conducted in either the bank or subsidiaries.

- Concen3: the share of the largest three banks in total banking assets. From World Bank Regulation and Supervision Database (2001).

- Concen5: the percentage of deposits accounted for by the five largest banks. From World Bank Regulation and Supervision Database (2001).

- Denied: the share of banking license applications rejected. From World Bank Regulation and Supervision Database (2001).

- Foreign Bank Share: the share of assets in banks that are majority foreign owned. From World Bank Regulation and Supervision Database (2001).

- State-owned Bank Share: the share of assets in banks that are majority stateowned. From World Bank Regulation and Supervision Database (2001).

- Private Credit: Bank claims on the private sector as share of GDP averaged over 1996-1999. From International Financial Statistics and World Economic Outlook.

- Market Capitalization: Stock market capitalization as share of GDP averaged over 1996-1999. From International Financial Statistics and World Economic Outlook.

- Financial Development: Logarithm of the sum of Private Credit and Market Capitalization.

- Financial Structure: Logarithm of the ratio of Private Credit to Market Capitalization.

- Institutional and legal development measures: 
- Institution: average of six indicators measuring Voice and Accountability, Political Stability, Regulatory Quality, Government Effectiveness, Control of Corruption, and Rule Of Law. Voice and Accountability indicates the extent to which the citizens of a country can participate in the selection of governments and the independence of the media. Political Stability measures the perception of the likelihood that the government in power will be destabilized or overthrown by uninstitutional and/or violent means. Government Effectiveness measures perceptions of the quality of public service provision, the quality of the bureaucracy, the competence of civil servants, the independence of the civil service from political pressures and the credibility of the government's commitment to policies. Rule of Law measures the extent agents have confidence in and abide by the rules of the society. From Kaufman, Kraay and Zoido-Lobaton (1999).

- Civil: whether the legal origin of a country is civil law or common law. From Reynolds and Flores (1996).

The following three variables consider securities laws regarding the issuance of new equity to the public.

- Disclosure: an index of disclosure requirements in security issuing regarding the prospectus, the compensation of the issuer's directors and key officers, the issuer's equity ownership structure, the equity ownership of issuer's shares by its directors and key officers, the issuer's contracts outside the ordinary course of business, and transactions between the issuer and its directors, officers, and/or large shareholders. A higher value for this index indicates stricter requirements in information disclosure. From La Porta, Lopez-De-Silanes, and Shleifer (2006).

- Liability: an index of liability standards for the security issuer and its directors, distributors, and accountants. A higher value for this index indicates that it is easier for investors to recover losses from the responsible party due to misleading information in prospectus or audited financial reports accompanying the prospectus. From La Porta, Lopez-De-Silanes, and Shleifer (2006).

- Public Enforcement: the average of six indices: 1) supervisor characteristic index; 2) rule-making power index; 3) investigative powers index; 4) orders index; and 5) criminal index. The supervisor characteristic index is an index of the appointment, tenure, and composition of the supervisor of securities markets. The 
rule-making power index is an index of the power of the supervisor to issue regulations regarding primary offerings and listing rules on stock exchanges. The investigative index measures the power of the supervisor to command documents or subpoena the testimony of witnesses when investigating an violation of securities laws. The orders index aggregates stop and do orders that may be directed to the issuer, the distributor, or the accountant in case of a defective prospectus. The criminal index is an index of criminal sanctions applicable to the issuer's directors and key officers, the distributor, or the accountant when the prospectus omits material information. The higher value the average of these six indices takes, the stronger the power of a public enforcer of securities laws is. From La Porta, Lopez-De-Silanes, and Shleifer (2006).

- Credit Registry: a dummy variable indicating whether there is a private credit registry in a country. From Djankov, McLiesh and Shleifer (2007).

- Accounting Standards: the average percentage availability of seven groups of information in companies' annual reports. The seven groups of information are general information, income statement, balance sheet, funds flow statement, accounting policies, stockholders' information and supplementary information. From International Accounting and Auditing Trends (4th edition) published by the Center for International Financial Analysis and Research (CIFAR).

- Stock Synchronization: a measure of the synchronization of stock price movements in a country. It is constructed as the average $R^{2}$ of firm level regressions of biweekly stock returns on market indexes in each country in 1995. From Morck, Yeung, and Yu (2000).

\subsection{Tables}


Table 1: Table of Country Level Variables

Security is a variable indicating the ability of banks to engage in security businesses. Institution measures the institutional development of a country. State-owned Bank Share is the share of assets in banks that are majority state-owned. Concen3 measures banking concentration and is the share of the largest three banks in total banking assets. Economic Freedom measures the extent to which institutional factors are inconsistent with promoting economic freedom. Accounting Standards measures the amount of information disclosure of companies' annual reports in a country. Detailed definitions and sources are in the data appendix. The countries are ordered by GDP per capita.

\begin{tabular}{|c|c|c|c|c|c|c|}
\hline & Security & Institution & $\begin{array}{l}\text { State-owned } \\
\text { Bank Share }\end{array}$ & Concen3 & $\begin{array}{l}\text { Economic } \\
\text { Freedom }\end{array}$ & $\begin{array}{l}\text { Accounting } \\
\text { Standards }\end{array}$ \\
\hline Nigeria & 2 & -1 & 13 & 0.34 & 3.43 & 70 \\
\hline Ghana & 2 & -0.14 & 37.9 & 0.57 & 3.39 & \\
\hline Zambia & 1 & -0.2 & 23 & 0.59 & 2.98 & \\
\hline India & 1 & 0 & 80 & 0.37 & 3.89 & 61 \\
\hline Bolivia & 2 & 0.02 & 0 & 0.52 & 2.57 & \\
\hline Indonesia & 2 & -0.77 & 44 & 0.38 & 3.05 & \\
\hline Egypt & 2 & -0.15 & 66.6 & 0.56 & 3.36 & \\
\hline Philippines & 1 & 0.21 & 12.12 & 0.32 & 3.03 & 64 \\
\hline Guatemala & 3 & -0.51 & 7.61 & 0.28 & 2.99 & \\
\hline Romania & 2 & -0.08 & 70 & 0.75 & 3.28 & \\
\hline El Salvador & 2 & -0.03 & 7 & 0.53 & 2.55 & \\
\hline Peru & 2 & -0.18 & 2.5 & 0.48 & 2.90 & \\
\hline Lithuania & 2 & 0.26 & 44 & 0.58 & 3.11 & \\
\hline Thailand & 2 & 0.15 & 30.67 & 0.42 & 2.55 & 66 \\
\hline Turkey & 3 & -0.33 & 35 & 0.38 & 2.79 & 58 \\
\hline Panama & 1 & 0.11 & 11.56 & 0.22 & 2.51 & \\
\hline Poland & 2 & 0.7 & 43.7 & 0.41 & 3.04 & \\
\hline Mexico & 3 & -0.07 & 25 & 0.39 & 3.34 & 71 \\
\hline Venezuela & 2 & -0.37 & 4.87 & 0.40 & 3.50 & \\
\hline Botswana & 1 & 0.56 & 2.39 & 0.90 & 2.97 & \\
\hline South Africa & 2 & 0.11 & 0 & 0.67 & 3 & 79 \\
\hline Brazil & 2 & 0 & 51.5 & 0.30 & 3.40 & 56 \\
\hline Malaysia & 2 & 0.51 & 0 & 0.30 & 2.68 & 79 \\
\hline \multicolumn{7}{|l|}{ Trinidad } \\
\hline \& Tobago & 3 & 0.59 & 15 & 0.54 & 2.60 & \\
\hline Croatia & 2 & 0.03 & 36.99 & 0.56 & 3.58 & \\
\hline Hungary & 2 & 0.87 & 3 & 0.42 & 2.99 & \\
\hline Chile & 2 & 0.88 & 11.7 & 0.25 & 2.26 & 78 \\
\hline \multicolumn{7}{|l|}{ Czech } \\
\hline Republic & 1 & 0.68 & 19 & 0.42 & 2.35 & \\
\hline Argentina & 2 & 0.33 & 30 & 0.27 & 2.50 & 68 \\
\hline Slovenia & 2 & 0.85 & 39.6 & 0.47 & 3.40 & \\
\hline Portugal & 1 & 1.2 & 20.8 & 0.28 & 2.48 & 56 \\
\hline Spain & 1 & 1.1 & 0 & 0.43 & 2.56 & 72 \\
\hline Italy & 1 & 0.91 & 17 & 0.27 & 2.44 & 66 \\
\hline UK & 1 & 1.5 & 0 & 0.27 & 1.92 & 85 \\
\hline Canada & 1 & 1.43 & 0 & 0.53 & 2.10 & 75 \\
\hline Singapore & 1 & 1.44 & 0 & 0.43 & 1.60 & 79 \\
\hline France & 1 & 1.03 & 0 & 0.32 & 2.38 & 78 \\
\hline US & 3 & 1.3 & 0 & 0.22 & 1.95 & 76 \\
\hline Sweden & 1 & 1.53 & 0 & 0.57 & 2.35 & 83 \\
\hline Germany & 1 & 1.37 & 42 & 0.36 & 2.31 & 67 \\
\hline
\end{tabular}


Table 2: Summary Statistics

Security is a variable indicating the ability of banks to engage in security businesses. Private Credit is bank claims on the private sector as a share of GDP. Market Capitalization is total market capitalization as a share of GDP. Turnover Ratio is the ratio of the value of stock transactions to market capitalization. Total Value Traded is the ratio of total value of domestic equities traded on domestic exchanges to GDP. Institution measures the institutional development. Civil is a dummy that takes 1 if the legal origin of a country is civil law. Foreign Bank Share is the share of assets in banks that are majority foreign owned. Concen3 (Concen5) is the share of the largest three (five) banks in total banking assets. Denied is the share of banking license applications rejected. Economic Freedom is an overall measure of the absence of government coercion or constraint on the economy. Disclosure is an index of information disclosure requirements. Liability is a measure of the liability standards. Public Enforcement is a measure of the power of a public enforcer of securities laws. Securities Laws is the average of Disclosure, Liability, and Public Enforcement. Detailed definitions and sources are in the data appendix.

\begin{tabular}{lcccccc} 
Variable & N & Mean & St. Dev. & Min & Median & Max \\
\hline Sales Growth & 3461 & 17.71 & 42.83 & -70 & 15 & 300 \\
Small & 3452 & 0.37 & 0.48 & 0 & 0 & 1 \\
Medium & 3452 & 0.42 & 0.49 & 0 & 0 & 1 \\
Large & 3452 & 0.21 & 0.41 & 0 & 0 & 1 \\
Log of Sales & 2514 & 16.15 & 4.08 & -2.12 & 16.32 & 25.33 \\
Export & 3402 & 0.43 & 0.49 & 0 & 0 & 1 \\
Foreign & 3427 & 0.23 & 0.42 & 0 & 0 & 1 \\
Govern & 3423 & 0.09 & 0.29 & 0 & 0 & 1 \\
Manufacture & 3207 & 0.39 & 0.49 & 0 & 0 & 1 \\
Service & 3207 & 0.46 & 0.50 & 0 & 0 & 1 \\
Construction & 3207 & 0.09 & 0.29 & 0 & 0 & 1 \\
Agriculture & 3207 & 0.03 & 0.16 & 0 & 0 & 1 \\
No. of Competitors & 3439 & 2.31 & 0.70 & 0 & 2 & 9 \\
General Credit Constraint & 3154 & 2.67 & 1.13 & 1 & 3 & 4 \\
High Interest Rate & 3297 & 3.18 & 1.02 & 1 & 4 & 4 \\
Log GDP per capita & 40 & 8.29 & 1.30 & 5.54 & 8.21 & 10.34 \\
Real GDP Growth & 40 & 3.27 & 1.81 & -2.02 & 3.64 & 6.25 \\
Inflation & 40 & 0.12 & 0.17 & -0.016 & 0.065 & 0.74 \\
Security & 40 & 1.75 & 0.67 & 1 & 2 & 3 \\
Private Credit & 40 & 0.45 & 0.33 & 0.044 & 0.35 & 1.16 \\
Market Capitalization & 40 & 0.42 & 0.47 & 0.003 & 0.22 & 1.84 \\
Financial Development & 40 & -0.54 & 0.96 & -2.44 & -0.56 & 1.03 \\
Financial Structure & 40 & 0.44 & 1 & -1.05 & 0.34 & 3.35 \\
Institution & 40 & 0.40 & 0.66 & -1 & 0.24 & 1.53 \\
Civil & 40 & 0.7 & 0.46 & 0 & 1 & 1 \\
State-owned Bank Share & 40 & 21.19 & 21.85 & 0 & 14 & 80 \\
Foreign Bank Share & 37 & 22.81 & 22.87 & 0 & 12.5 & 97.61 \\
Concen3 & 40 & 0.43 & 0.15 & 0.22 & 0.41 & 0.90 \\
Concen5 & 36 & 0.60 & 0.21 & 0.12 & 0.62 & 1 \\
Denied & 24 & 0.26 & 0.28 & 0 & 0.23 & 1 \\
Economic Freedom & 40 & 2.80 & 0.51 & 1.60 & 2.85 & 3.89 \\
Disclosure & 25 & 0.64 & 0.24 & 0.17 & 0.58 & 1 \\
Liability & 25 & 0.48 & 0.29 & 0 & 0.39 & 1 \\
Public Enforcement & 25 & 0.59 & 0.2 & 0.22 & 0.6 & 0.9 \\
Credit Registry & 39 & 0.72 & 0.46 & 0 & 1 & 1 \\
Accounting Standards & 21 & 70.81 & 8.70 & 56 & 71 & 85 \\
Stock Synchronization & 22 & 0.202 & 0.130 & 0.021 & 0.184 & 0.569 \\
\hline & & & & & & \\
\hline
\end{tabular}




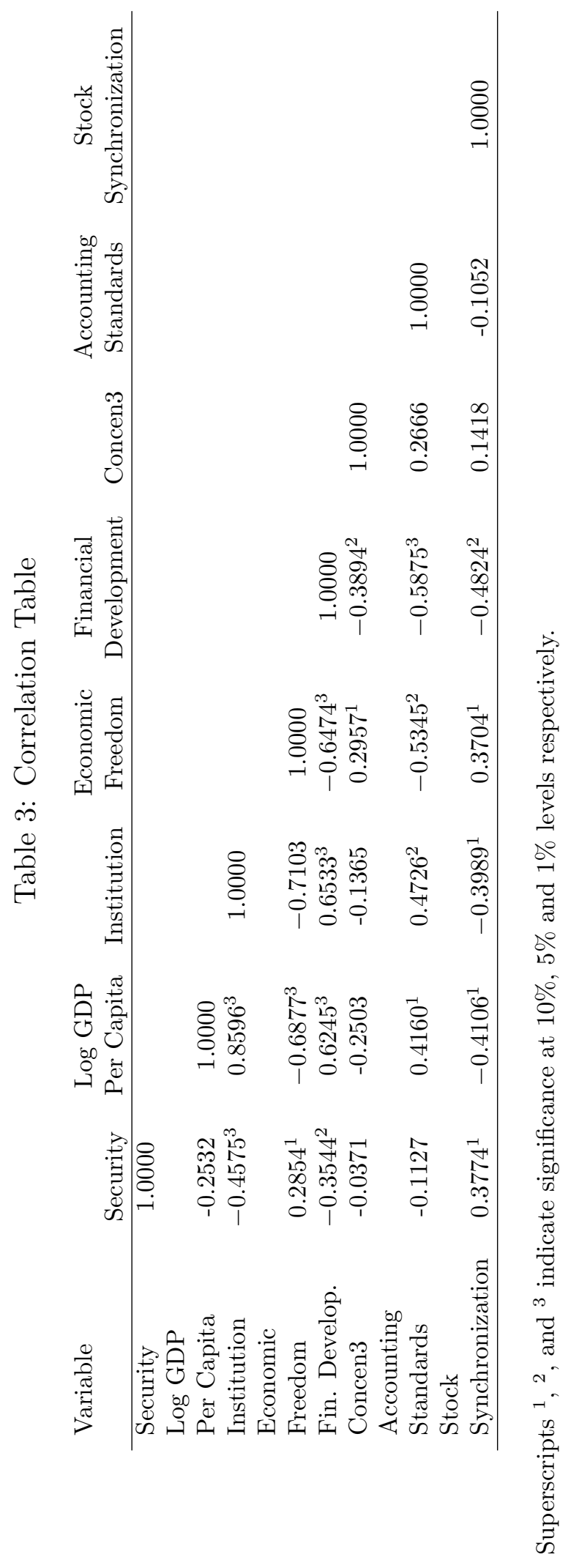


Table 4: Universal Banking and Firm Growth

This table reports results of OLS regressions of firm sales growth on firm level and country level variables with robust error estimation clustered by country. Variables that are included in the regressions but not reported are the two firm size dummies (the omitted category is 'Large'), the four industry dummies (the omitted category is 'Other'), 'Log of Competitors', 'Export', 'Foreign', 'Govern', 'Log of GDP per capita', 'GDP growth', 'Inflation', 'Institution', 'Civil', 'Financial Development', 'Financial Structure', 'Economic Freedom', and 'State-owned Bank Share'. In columns (a)-(d), different measures of government intervention in the economy are included. In columns (e), differential effects across firm sizes are explored. Robust standard errors that have been adjusted for country level clustering are included in parentheses. All variables are described in the appendix. Superscripts ${ }^{1},{ }^{2}$, and ${ }^{3}$ indicate significance at $10 \%, 5 \%$ and $1 \%$ levels respectively.

\begin{tabular}{|c|c|c|c|c|c|}
\hline & (a) & $\overline{(\mathrm{b})}$ & (c) & $\overline{(\mathrm{d})}$ & (e) \\
\hline Security & $\begin{array}{l}7.52^{2} \\
(3.12)\end{array}$ & $\begin{array}{l}6.08^{2} \\
(2.98)\end{array}$ & $\begin{array}{l}14.18^{3} \\
(1.90)\end{array}$ & $\begin{array}{l}6.18^{2} \\
(3.11)\end{array}$ & \\
\hline Security $\times$ Small & & & & & $\begin{array}{c}4.54 \\
(3.67)\end{array}$ \\
\hline Security $\times$ Medium & & & & & $\begin{array}{l}10.29^{3} \\
(3.41)\end{array}$ \\
\hline Security $\times$ Large & & & & & $\begin{array}{l}7.41^{2} \\
(3.58)\end{array}$ \\
\hline Concen3 & $\begin{array}{c}5.03 \\
(11.01)\end{array}$ & & & & $\begin{array}{c}4.67 \\
(10.82)\end{array}$ \\
\hline Concen5 & & $\begin{array}{l}16.40^{1} \\
(8.10)\end{array}$ & & & \\
\hline Denied & & & $\begin{array}{l}14.58^{2} \\
(7.43)\end{array}$ & & \\
\hline Foreign Bank & & & & $\begin{array}{l}-0.022 \\
(0.066)\end{array}$ & \\
\hline Observations & 3057 & 2772 & 1741 & 2876 & 3057 \\
\hline$R^{2}$ & 0.0529 & 0.0597 & 0.0719 & 0.0564 & 0.0542 \\
\hline
\end{tabular}


Table 5: Universal Banking and Firm Growth: Country Characteristics

This table reports results for regressions of firm sales growth on interaction terms between security and 7 country characteristics in addition to other firm level and country level controls. Variables that are included in the regressions but not reported are the two firm size dummies (the omitted category is 'Large'), the four industry dummies (the omitted category is 'Other'), 'Log of Competitors', 'Export', 'Foreign', 'Govern', 'Nonfinancial', 'Real Estate', 'Insurance', 'Log of GDP per capita', 'GDP growth', 'Inflation', 'Institution', 'Civil', 'Financial Development', 'Financial Structure', 'Concen3', and 'State-owned Bank Share'. Robust standard errors that have been adjusted for country level clustering are included in parentheses. All variables are described in the appendix. Superscripts ${ }^{1},{ }^{2}$, and ${ }^{3}$ indicate significance at $10 \%, 5 \%$ and $1 \%$ levels respectively.

\begin{tabular}{|c|c|c|c|c|c|c|c|}
\hline & (a) & (b) & (c) & (d) & (e) & $\overline{(f)}$ & $(\mathrm{g})$ \\
\hline Security & $\begin{array}{l}10.40^{3} \\
(4.18)\end{array}$ & $\begin{array}{c}20.31 \\
(17.03)\end{array}$ & $\begin{array}{l}15.18^{3} \\
(4.89)\end{array}$ & $\begin{array}{c}35.24^{3} \\
(9.50)\end{array}$ & $\begin{array}{l}40.61^{3} \\
(10.90)\end{array}$ & $\begin{array}{l}13.74^{3} \\
(2.59)\end{array}$ & $\begin{array}{c}-8.81^{2} \\
(3.92)\end{array}$ \\
\hline Institution & $\begin{array}{l}30.69^{3} \\
(11.13)\end{array}$ & & & & & & \\
\hline Security $\times$ & -4.15 & & & & & & \\
\hline Institution & $(4.36)$ & & & & & & \\
\hline Disclosure & & $\begin{array}{c}48.67 \\
(33.13)\end{array}$ & & & & & \\
\hline Security $x$ & & -9.62 & & & & & \\
\hline Disclosure & & $(19.30)$ & & & & & \\
\hline Liability & & & $\begin{array}{c}-0.28 \\
(13.84)\end{array}$ & & & & \\
\hline Security $\times$ & & & $-13.20^{1}$ & & & & \\
\hline Liability & & & $(6.45)$ & & & & \\
\hline Public Enforcement & & & & $\begin{array}{c}39.80 \\
(26.45)\end{array}$ & & & \\
\hline Security $x$ & & & & $-34.11^{3}$ & & & \\
\hline Public Enforcement & & & & $(11.81)$ & & & \\
\hline Accounting Standards & & & & & $\begin{array}{l}1.20^{3} \\
(0.25)\end{array}$ & & \\
\hline Security $\times$ & & & & & $-0.49^{3}$ & & \\
\hline Accounting Standards & & & & & $(0.14)$ & & \\
\hline Credit Registry & & & & & & $\begin{array}{c}14.28^{3} \\
(3.18)\end{array}$ & \\
\hline Security $\times$ & & & & & & $-10.66^{3}$ & \\
\hline Credit Registry & & & & & & $(1.60)$ & \\
\hline Stock Synchronization & & & & & & & $\begin{array}{c}-197.27^{3} \\
(45.14)\end{array}$ \\
\hline Security $x$ & & & & & & & $122.96^{3}$ \\
\hline Stock Synchronization & & & & & & & $(20.78)$ \\
\hline Observations & 3057 & 1969 & 1969 & 1969 & 1748 & 2998 & 1941 \\
\hline Countries & 40 & 25 & 25 & 25 & 21 & 39 & 22 \\
\hline$R^{2}$ & 0.0537 & 0.1009 & 0.1085 & 0.1039 & 0.1105 & 0.0703 & 0.0935 \\
\hline
\end{tabular}


Table 6: Universal Banking and Firm Growth: Nonlinear Effect

This table reports results for regressions that consider nonlinear effects of 'Security'. 'Security1' equals 1 if 'Security' is equal to 1; 'Security2' equals 1 if 'Security' is equal to 2 . The dependent variable is firm sales growth. Variables that are included in the regressions but not reported in the table are the two firm size dummies (the omitted category is 'Large'), the four industry dummies (the omitted category is 'Other'), 'Log of Competitors', 'Export', 'Foreign', 'Govern', 'Log of GDP per capita', 'GDP growth', 'Inflation', 'Institution', 'Civil', 'Financial Development', 'Financial Structure', 'Economic Freedom', and 'State-owned Bank Share'. In columns (a)-(d), different measures of banking competition are considered. Robust standard errors that have been adjusted for country level clustering are included in parentheses. All variables are described in the appendix. Superscripts ${ }^{1},{ }^{2}$, and ${ }^{3}$ indicate significance at $10 \%, 5 \%$ and $1 \%$ levels respectively.

\begin{tabular}{lcccc}
\hline \hline & $(\mathrm{a})$ & $(\mathrm{b})$ & $(\mathrm{c})$ & $(\mathrm{d})$ \\
\hline Security1 & $-15.08^{2}$ & $-12.28^{2}$ & $-22.60^{3}$ & $-10.94^{1}$ \\
& $(6.38)$ & $(5.37)$ & $(3.90)$ & $(6.40)$ \\
Security2 & -7.60 & -6.29 & -2.58 & -4.04 \\
& $(5.65)$ & $(5.28)$ & $(4.25)$ & $(6.55)$ \\
Concen3 & 5.05 & & & \\
& $(10.99)$ & & & \\
Concen5 & & $16.48^{1}$ & & \\
& & $(8.22)$ & & \\
Denied & & & $12.68^{2}$ & \\
& & & $(5.85)$ & \\
Foreign Bank & & & & -0.036 \\
& & & & \\
\hline Wald Tests (P-values): & & & & \\
Security1 & 0.0869 & 0.0802 & 0.0000 & 0.1010 \\
\hline Security2 & 3057 & 2772 & 1741 & 2876 \\
\hline Observations & 0.0529 & 0.0597 & 0.0744 & 0.0565 \\
$R^{2}$ & & & & \\
\hline \hline
\end{tabular}


Table 7: Universal Banking and Firms' Access to Finance

This table reports results of ordered probit regressions of credit constraint on firm level and country level variables with robust error estimation clustered by country. In columns (a)-(d), the dependent variable measures how problematic financing is for firms' growth and operation. In column (e), the dependent variable measures financing constraint related to high interest rates. Both variables take values 1-4 with higher values indicating higher credit constraint. Variables that are included in the regressions but not reported are the two firm size dummies (the omitted category is 'Large'), the four industry dummies (the omitted category is 'Other'), 'Log of Competitors', 'Export', 'Foreign', 'Govern', 'Log of GDP per capita', 'GDP growth', 'Inflation', 'Institution', 'Civil', 'Financial Development', 'Financial Structure', 'Economic Freedom', and 'State-owned Bank Share'. Robust standard errors that have been adjusted for country level clustering are included in parentheses. All variables are described in the appendix. Superscripts ${ }^{1},{ }^{2}$, and ${ }^{3}$ indicate significance at $10 \%, 5 \%$ and $1 \%$ levels respectively.

\begin{tabular}{lccccc}
\hline \hline & $\begin{array}{c}(\mathrm{a}) \\
\text { General } \\
\text { Constraint }\end{array}$ & $\begin{array}{c}(\mathrm{b}) \\
\text { General } \\
\text { Constraint }\end{array}$ & $\begin{array}{c}\text { General } \\
\text { Constraint }\end{array}$ & $\begin{array}{c}\text { General } \\
\text { Constraint }\end{array}$ & $\begin{array}{c}\text { High } \\
\text { Interest Rates }\end{array}$ \\
\hline Security & $0.23^{3}$ & $0.23^{3}$ & $0.17^{3}$ & $0.28^{3}$ & $0.34^{3}$ \\
& $(0.07)$ & $(0.07)$ & $(0.04)$ & $(0.07)$ & $(0.07)$ \\
Concen3 & $0.37^{1}$ & & & & -0.027 \\
& $(0.22)$ & & & & $(0.41)$ \\
Concen5 & & 0.13 & & & \\
& & $(0.16)$ & & & \\
Denied & & & $0.37^{3}$ & & \\
Foreign Bank & & & $(0.09)$ & & 0.001 \\
& & & & $(0.001)$ & \\
\hline Observations & 2777 & 2495 & 1650 & 2598 & 2914 \\
$R^{2}$ & 0.0545 & 0.0482 & 0.0528 & 0.0544 & 0.1039 \\
\hline \hline
\end{tabular}


Table 8: Universal Banking and Firm Growth: Sub-Samples

This table reports results of OLS regressions of firm sales growth on firm level and country level variables with robust error estimation clustered by country. Variables that are included in the regressions but not reported are the two firm size dummies (the omitted category is 'Large'), the four industry dummies (the omitted category is 'Other'), 'Log of Competitors', 'Export', 'Foreign', 'Govern', 'Log of GDP per capita', 'GDP growth', 'Inflation', 'Institution', 'Civil', 'Financial Development', 'Financial Structure', 'Economic Freedom', and 'State-owned Bank Share'. In column (a), the full sample is used. In columns (b), only countries not in the European Union by 2000 are considered. In column (c), only developing countries are considered. Robust standard errors that have been adjusted for country level clustering are included in parentheses. All variables are described in the appendix. Superscripts ${ }^{1},{ }^{2}$, and ${ }^{3}$ indicate significance at $10 \%, 5 \%$ and $1 \%$ levels respectively.

\begin{tabular}{lccc}
\hline \hline & $\begin{array}{c}\text { (a) } \\
\text { Full } \\
\text { Sample }\end{array}$ & $\begin{array}{c}\text { (b) } \\
\text { Non-EU } \\
\text { Countries }\end{array}$ & $\begin{array}{c}\text { (c) } \\
\text { Developing } \\
\text { Countries }\end{array}$ \\
\hline Security & $7.52^{2}$ & $10.52^{3}$ & $10.46^{3}$ \\
& $(3.12)$ & $(3.09)$ & $(3.23)$ \\
Nonfinancial & -0.82 & 1.18 & $3.87^{2}$ \\
& $(2.14)$ & $(2.14)$ & $(1.77)$ \\
Real Estate & -2.66 & $-6.82^{2}$ & $-11.20^{3}$ \\
& $(2.41)$ & $(2.97)$ & $(2.29)$ \\
Insurance & 0.058 & -1.08 & $3.70^{2}$ \\
& $(3.16)$ & $(2.73)$ & $(1.81)$ \\
Concen3 & 5.03 & 12.85 & 10.29 \\
& $(11.01)$ & $(11.87)$ & $(10.34)$ \\
\hline Observations & 3057 & 2653 & 2519 \\
$R^{2}$ & 0.0529 & 0.0643 & 0.0757 \\
\hline \hline
\end{tabular}

